\title{
Democratic Stability in Mitigating the Impact of Corruption on Economic Growth in Nigeria
}

\author{
Isiwu George Duhu, PhD \\ Department of Economics, Enugu State University of Science and \\ Technology, Enugu, Nigeria
}

Doi:10.19044/esj.2019.v15n31p106 URL:http://dx.doi.org/10.19044/esj.2019.v15n31p106

\begin{abstract}
Corruption and its practices in Nigeria have become systemic in both public and private sectors. Following the consolidation of democracy in the country since 1999 to date, there is a problem as to whether democratic stability has helped in mitigating the impact of corruption on economic growth. The main objective of this study is to identify whether democratic stability helps in mitigating the impact of corruption on Economic growth in Nigeria. Annual time series data on real GDP growth rate, corruption perception index (proxy for corruption), life expectancy at birth, population growth rate and government expenditure were the variables used for the study, covering the period 1996-2017. Dummy variable was also used as a proxy for democracy. To analyse the data, Autoregressive Distributed lag (ARDL) model was adopted. The empirical results show that corruption has negative impact on economic growth, implying that increase in corruption decreases economic growth; and that democratic stability helps in mitigating the impact of corruption on economic growth in Nigeria during the period covered by the study. The study, therefore, recommends that the government should enforce the democratic principles such as the rule of law, government's responsiveness to public opinion, freedom of speech, freedom of religion and most importantly, political participation by the citizens. Such democratic principles, when enforced, will provide more stable environment for investments and hence promote growth. The various anti-corruption agencies like the EFCC and ICPC should also, without fear or favour, bring to book all corrupt politicians and bureaucrats in our public service.
\end{abstract}

Keywords: Corruption, Democracy, Economic Growth, ARDL 


\section{Introduction}

\section{Background of the Study.}

One of the major macroeconomic policy objectives of every country is to achieve rapid economic growth. However, one of the major factors inhibiting growth in Nigeria as stated in the National Economic Empowerment and Development Strategy (NEEDS) macroeconomic framework (2004) is pervasive rent- seeking and corruption. This has made growth of the Nigerian economy to be disappointing in recent years.

The Central Bank of Nigeria (CBN) Annual Report (2017) shows that real GDP growth rate in 2013 is 5.5 percent. This increased to 6.2 percent in 2014 but declined to 2.8 percent in 2015 . It recorded a negative growth rate of -1.6 percent in 2016 and slow growth of 0.8 in 2017.

The political Bureau of the Federal Republic of Nigeria, in its 1987 report, outlines the multifarious manifestation of corruption to include: the inflation of government contracts in return for kickbacks; fraud and falsification of accounts in the public service; examination malpractices in our educational institutions, the taking of bribes and perversion of justice among the police, the judiciary and other organs for administering justice; and various heinous crimes against the state in business and industrial sectors of the economy. These include collusion with multinational companies such as overinvoicing of goods, foreign exchange swindling, hoarding and smuggling. This definition is broad because it covers all facets of corruption in the country.

World Bank (1997) defines corruption as the abuse of public office for private gains. Public office, in this context, is abused when private agents actively accepts, solicits and extorts a bribe. Hence, Rose-Ackerman (1999) notes that corruption exists when institutions established to regulate the interrelationships between the citizens and states are used instead for personal enrichment and provision of benefits to the corrupt and undeserving.

In line with the above, El-Rufai (2003) notes that corruption in Nigeria covers a wide range of social misconduct ranging from embezzlement, bribery, nepotism, influence, peddling, bestowing of favours to friends, rigging of elections, abuse of public property, sale of fake or expired drugs, etc.

The Transparency International (TI)'s Corruption Perception Index (CPI), which is used as a proxy for corruption, categorises corruption into three parts

a. Grand Corruption: This refers to acts committed at high level of government that distort policies or the central functioning of the state, enabling leaders to benefit at the expense of the public good.

b. Petty Corruption: This refers to everyday abuse of entrusted power by low and mid-level public officials in their interactions with ordinary citizens ... often trying to access basic public goods and services. 
c. Political corruption: This refers to manipulation of policies, institutions and rules of procedure in the allocation of resources and financing by political decision makers, who abuse their position to sustain their power, status and wealth.

\subsection{Statement of the Problem}

The unnerving effects of corruption and democratization process in Nigeria have continued to attract national discourse in recent years. This is because corruption undermines the integrity of government and public institutions.

Obasanjo (2000), notes that corruption has been responsible for the political instability of successive governments in Nigeria since the First Republic. NEEDS (2004:8) reports that more than 200 Nigerians were being detained or tried for fraud, and for illegally obtained assets worth more than \$500million which has been confisticated.

Following the consolidation of democracy in Nigeria since 1999, corruption and financial crimes are being vigorously tackled. The government in power in 1999 instituted anti-graft agencies aimed at fighting corruption in the country. They include: The Independent Corrupt Practices and other Related Offences Commission (ICPC) in the year 2000; Economic and Financial Crimes Commission (EFCC) Establishment Act (2004) and Money Laundering (Prohibition) Act (2004). In the same vein, the current government in power, on assuming office in May 2015, launched anti-corruption drive in the country.

In recent years, Nigeria has been rated as one of the most corrupt countries in the world by the Transparency International (TI). In 2013, Nigeria came $144^{\text {th }}$ out of 177 countries that were assessed. In 2014 , she came $136^{\text {th }}$ out 175 countries; $136^{\text {th }}$ out of 168 countries in $2015 ; 136^{\text {th }}$ out of 176 countries surveyed in 2016; and $148^{\text {th }}$ out of 180 countries that were assessed in 2017.

Since Nigeria has been experiencing stable democracy (Uninterrupted civilian rule) since 1999 to date, it is useful to assess whether democratic stability has helped in mitigating the impact of corruption on economic growth in Nigeria.

\subsection{Objectives of the Study}

This study intends to achieve the following objectives.

1. To analyse the impact of corruption on economic growth in Nigeria.

2. To identify whether democratic stability helps in mitigating the impact of corruption on economic growth in Nigeria. 
This research is divided into five sections. Section one is the introductory section, which comprises the background of the study, statement of the problem and objectives of the study. Section two is the literature review, which comprises the theoretical and empirical literature. Section three presents the methodology, showing the basic model and its specification and the analytical framework. Section four presents and discusses the results of the findings, while the last section, section five, presents the summary of the findings, conclusion and recommendations

\section{Literature Review \\ 2.1 Theoretical Literature}

A good number of scholars emphasise the impact of corruption on economic growth from theoretical perspective. The debates focus on two competing hypotheses, whether corruption 'greases the wheels' or 'sands the wheels' of bureaucracy. Scholars in the first stream of debate argue that corruption eliminates the bureaucratic structure that delays the financial decisions and prevents investment and thus, accelerates growth (leff, 1964; Nye, 1967; Huntington, 1968; leys, 1970; lui, 1985, Wedeman, 1997; Meon and Sekkat, 2005). For instance, leff (1964), Nye (1967), Huntington (1968) argue that bribery may decease bureaucratic costs and accelerate efficient public administration. They note that as bureaucratic procedures are stimulated and bureaucratic costs drop, economic growth is promoted. Thus, these scholars are aligned with the hypothesis that corruption greases the wheels of bureaucracy, which implies that corruption has positive impact on economic growth.

Scholars in the second stream of debate argue that corruption can be fatal to economic activity because it makes bureaucratic procedures sluggish, expensive, and inefficient and also diverts resources to unproductive activities (Myrdal, 1968; Shleifer and Vishny, 1993; Tanzi and Davoodi, 1997; and Mauro, 1998). For instance, Shleifer and Vishny (1993) argue that resources may be shifted away from productive activities (education and health) to potentially useless projects (defence) if meaningful secrecy in the latter is easier. In line with the above, Hodge, Sriran Shankar, Prasada and Alan (2011) argue that corruption emerges as a negative construct that erodes property rights, harms political institutions and complicates the nature of economic development. These scholars are aligned with the hypothesis that corruption sands the wheels of bureaucracy, which implies that corruption has negative impact on economic growth.

The foregoing shows that both 'greases the wheels' (positive impact of corruption on Economic growth) and 'sands the wheels' (Negative impact of corruption on economic growth) lies in the interaction between corruption and institutional feature (democracy) (Shabbir, 2017). This study incorporates the 
institutional feature (democracy) in order to identify which of the hypotheses holds for Nigeria.

\subsection{Empirical Literature}

There has been existing controversy on the relationship between corruption, democracy and economic growth. Scholars in the first stream of debate argue, through their empirical studies, that corruption can affect economic growth negatively. The scholars in this first school include Mauro (1995), Knack and Keefer (1995), Mo (2001), Isse and Abdiweli (2003) and Omenka (2013).

In an empirical work on the relationship between corruption and economic growth, Mauro (1995) finds that there is a statistically negative effect of corruption on private investment rates. He notes that the cause of low investment is primarily due to institutional inefficiency.

In their analysis on the impact of corruption on economic growth, knack and Keefer (1995) included other indicators such as the performance of the bureaucracy, voice and accountability and security of property rights. They used political risks services as a proxy for corruption. The results show that corruption has a negative effect on economic growth.

MO (2001), in an empirical study on the impact of corruption on economic growth and the importance of transmission channels, finds that increase in corruption leads to lower economic growth and that political instability is one of the most important channels through which corruption affects economic growth.

In their study on the determinants of economic corruption, which involves cross-country comparison, Isse and Abdiweli (2003) find that corruption has negative and statistically significant effect on economic growth, the level of education, the legal effectiveness and economic freedom.

In Nigeria, Omenka (2013) examines the effects of corruption on Nigeria's development efforts. The study identifies the causes of corruption to include, poverty, pressure from families, communities' ethnic loyalties, among others. The result also shows that corruption leads to the depletion of national wealth.

However, scholars in the second school argue that corruption has a positive effect on economic growth (Leff, 1964; Huntington, 1968; Leys, 1970; Odubunmi and Agbelade, 2014; Oguonu and Ezeibe, 2014). Leff (1964) and Huntington (1968) note that corruption, essentially the speed money, can increase efficiency of the economic system. The speed money will help to reduce transaction costs and avoids bureaucratic delays. Thus, Leys (1970) argues that small side payments to the public office bearers could help in reducing the bureaucratic hindrances and thereby encouraging economic activity. Lui (1985) finds that corruption can reduce waiting time. In line with 
Lui (1985), Wedeman (1997) notes that the assumption that corruption systematically reduces growth is not entirely justified. He argues that many corrupt countries have growth rates high.

Some of the Nigerian studies also found positive relationship between corruption and economic growth. Odubunmi and Agbelade (2014), in their investigation on the causality relationship between corruption and economic growth in Nigeria, find that there is a uni-directional casualty between the two variables, where causality runs from corruption to economic growth.

Oguonu and Ezeibe (2014) examine the impact of political corruption on economic growth in Nigeria using data from documented evidence. Employing descriptive method, the result shows that there is a positive relationship between political corruption, democracy and economic growth and development in Nigeria.

Studies have equally been conducted on the link between democracy, corruption and economic growth in different countries. Clague, Keefer, Knack and Olson (1996) note that democracy provides greater safety and security to implement property rights than authoritarian regime.

Amira (2014) investigates the corruption's and democracy's effects on economic growth. The study utilized dynamic panel data approach for 42 countries (18 democratic and 24 non-democratic countries) for the period 2000 - 2011. The empirical results show that corruption has no significant effect on economic growth in democratic countries, while it has negative effect on economic growth in non-democratic countries that were sampled.

Aminu, Gbenga and Bolaji (2014) investigate the impact of democracy on the performance of the Nigerian economy for the period 1983-1998 (Military era) and 1999 - 2012 (Democracy era). The study adopted democracy led growth model, utilizing data on GDP (dependent variables) and poverty rate, unemployment rate, corruption index and inflation rate as independent variables. Employing ordinary least squares (O1S) techniques, the results show that unemployment rate, inflation rate, poverty level and corruption level raise output in the economy, while change in democracy reduces output in the economy. The results also show that there is no causality relationship between GDP and democracy, a uni-directional causality exists between corruption and GDP, where causality runs from GDP to corruption. They also found that GDP is higher during democracy than during the military era.

Shabbir (2017) examines corruption, democracy and economic growth in developing eight $(\mathrm{D}-8)$ countries (Bangladesh, Indonesia, Malaysia, Turkey, Egyt, Iran, Nigeria and Pakistan). Data on growth rate of real GDP (dependent variable) and corruption index, government expenditure, investment - Output ratio, population growth rate and education level (independent variables) were collected. Generalized method of moment 
(GMM) was used to estimate the panel data set. The empirical results indicate that democracy plays an essential role in determining the corruption-growth relationship.

Aliyu (2017) investigates revenues reforms, corruption and economic growth in Nigeria for the period 1999 - 2016. Data on GDP, gross revenue to GDP, corruption perception index, non-oil revenue to GDP and polity democracy score as index of democracy were utilized in the analysis. Applying Vector Error Correction (VEC) model to analyse the data, the empirical results show a long run equilibrium relationship between economic growth and non-oil revenue, gross revenue, corruption and democracy in Nigeria. The results further reveal a negative impact of corruption on economic growth and positive impact of democracy on economic growth.

\section{3. $\quad$ Methodology}

The methodology adopted in this research is purely econometrics, applying Autoregressive Distributed Lag (ARDL) model procedure. The choice of ARDL is guided by the fact that it is suitable to small samples; the sample size for this study is small (1996 - 2017). The choice of this period is guided by the data availability on corruption perception index for Nigeria; the comprehensive data for Nigeria started in 1996. It is also applied irrespective of the order of integration of the variables, I (0) or I (1) (Pesaran, Shin and Smith, 2001). Most importantly, ARDL has the advantage of generating long run and short run results simultaneously.

\subsection{Variable Description/Sources}

Table 1: List of variables, their definitions and sources

\begin{tabular}{|l|l|l|}
\hline \multicolumn{1}{|c|}{ Variable } & \multicolumn{1}{|c|}{ Definition } & \multicolumn{1}{c|}{ Sources } \\
\hline RGDPr & Real GDP growth rate. & $\begin{array}{l}\text { Central Bank of Nigeria (CBN) Statistical } \\
\text { Bulletin, 2017 }\end{array}$ \\
\hline CORRPUT & $\begin{array}{l}\text { Corruption proxied by corruption } \\
\text { perception index (CPI). }\end{array}$ & Transparency International, 2017 \\
\hline DEMO & $\begin{array}{l}\text { Dummy variable for democracy; DEMO = } \\
1 \text { from 1999 - 2017 and 0 for other years }\end{array}$ & Constructed by the author \\
\hline LEXB & Life Expectancy at Birth & CBN Annual Report (Various Issues) \\
\hline POPGR & Population Growth Rate & CBN Annual Report (various issues) \\
\hline LGEXP & Government Expenditure (in logarithm) & CBN Statistical Bulletin, 2017 \\
\hline
\end{tabular}

\subsection{Model Specification}

This study adopted the corruption-Growth Model by Meon and Sekkat (2005). In the model, this study used corruption, democracy and interaction term (corruption* democracy) as determinants of real GDP growth rate to identify whether democratic stability helps in mitigating the impact of corruption on economic growth in Nigeria. 
The long run relationship between economic growth (RGDPr) and independent variables is specified below.

$$
\begin{array}{cc}
\text { RGDP }_{\mathrm{rt}} & \beta_{0}+\beta_{1} \text { CORRUPT }_{\mathrm{t}}+\beta_{2} \mathrm{DEMO}_{\mathrm{t}}+\beta_{3} \mathrm{LEXB}_{\mathrm{t}}+\beta_{4} \mathrm{POPGR}_{\mathrm{t}}+ \\
& \beta_{5} \mathrm{LGEXP}_{\mathrm{t}}+\beta_{6} \mathrm{CORRUPT}^{*} \mathrm{DEMO}+\mu_{\mathrm{t}} \ldots 3.1
\end{array}
$$

Where, RGDPr, CORRUPT, DEMO, LEXB, POPGR and LGEXP are as defined above and CORRUPT*DEMO captures the interaction effect of corruption and democracy dummy.

$\beta_{0}$ is the constant intercept, while $\beta_{1}-\beta_{6}$ are the coefficients of the variables respectively. $\mu$ is the error term and $\mathrm{t}$ is the time period.

\subsection{Economic a priori of the variables}

The coefficient of corruption $\left(\beta_{1}\right)$ is expected to be negative; an increase in corruption reduces economic growth and vice versa. The coefficient of democracy $\left(\beta_{2}\right)$ is expected to be positive; democracy promotes economic growth. The coefficient of life expectancy at Birth $\left(\beta_{3}\right)$ is expected to be positive; healthy workers contribute to high productivity and thus, higher growth. The coefficient of population growth rate $\left(\beta_{4}\right)$ is expected to be positive; the higher the population growth, the higher the economic growth and vice versa. The coefficient of government expenditure $\left(\beta_{5}\right)$ is expected to be positive; the higher the government spending, the higher the growth. The coefficient of interaction effect of corruption and democracy $\left(\beta_{6}\right)$ is expected to be positive; when $\beta_{1}$ is negative and $\beta_{6}$ is positive, democracy mitigates the negative effect of corruption on growth.

\subsection{Method of Evaluation}

One of the conditions required for the application of ARDL is that none of the variables is integrated into order two, I(2). Hence, Augmented Dickey - Fuller (ADF) and Philips - Perron (PP) unit root tests were conducted before the application of ARDL approach to cointegration.

Following Pesaran et al (2001), the ARDL format of equation 3.1 above becomes;

$$
\Delta \mathrm{RGDP}_{\mathrm{rt}}=\beta_{0}+\sum_{i=1}^{p} \beta_{1} \Delta \mathrm{RGDP}_{\mathrm{rt}-\mathrm{i}}+\sum_{i=1}^{p} \beta_{2} \Delta \mathrm{CORRUPT}_{\mathrm{t}-\mathrm{i}}+\sum_{i=1}^{p} \beta_{3} \Delta \mathrm{DEMO}_{\mathrm{t}-\mathrm{i}}+
$$

$\sum_{i-1}^{p} \beta_{4} \Delta \mathrm{LEXB}_{\mathrm{t}-\mathrm{i}}+\sum_{i=1}^{p} \beta_{5} \Delta \mathrm{POPGR}_{\mathrm{t}-\mathrm{i}}+\sum_{i=1}^{p} \beta_{6} \Delta \mathrm{LGEXP}_{\mathrm{t}-\mathrm{i}}+\sum_{i=1}^{p} \beta_{7} \Delta$ CORRUPT $^{*}$ DEMO $_{\mathrm{t}-}$

${ }_{\mathrm{i}}+\lambda_{1} \mathrm{RGDP}_{\mathrm{rt}}+\lambda_{2}$ CORRUPT $_{\mathrm{t}}+\lambda_{3}$ DEMO $_{\mathrm{t}}+\lambda_{4} \mathrm{LEXB}_{\mathrm{t}}+\lambda_{5}$ POPGR $_{\mathrm{t}}+\lambda_{6} \mathrm{LEXP}_{\mathrm{t}}+$ $\lambda_{7}$ CORRUPT $*$ DEMO $+\Sigma_{\mathrm{t}} \ldots 3.2$

Where, $\mathrm{t}$ is time period, $\Delta$ is first difference operator, $\beta \mathrm{o}$ is the constant intercept, $\beta_{1}-\beta_{7}$, with summation signs, represent the short-run dynamics, while $\lambda_{1}-\lambda_{7}$ represent the long run coefficients. Ps are the respective specific optimum lag orders and $\Sigma$ is the error term. When cointegration between the dependent and independent variables exists, the error correction models (ECM), which describes the short run dynamics or adjustment of the cointegrated variables towards their equilibrium values, has to be estimated. 
The general error correction representation of equation 3.2 is presented as: $\Delta \mathrm{RGDP}_{\mathrm{rt}}=\beta_{0}+\sum_{i=1}^{p} \beta_{1} \Delta \mathrm{RGDP}_{\mathrm{rt}-\mathrm{i}}+\sum_{i=1}^{p} \beta_{2} \Delta \mathrm{CORRUPT}_{\mathrm{t}-\mathrm{i}}+\sum_{i=1}^{p} \beta_{3} \Delta \mathrm{DEMO}_{\mathrm{t}-\mathrm{i}}+$ $\sum_{i-1}^{p} \beta_{4} \Delta \mathrm{LEXB}_{\mathrm{t}-\mathrm{i}}+\sum_{i=1}^{p} \beta_{5} \Delta \mathrm{POPGR}_{\mathrm{t}-\mathrm{i}}+\sum_{i=1}^{p} \beta_{6} \Delta \mathrm{LGEXP}_{\mathrm{t}-\mathrm{i}}+\sum_{i=1}^{p} \beta_{7} \Delta \mathrm{CORRUPT}^{*} \mathrm{DEMO}_{\mathrm{t}-}$ $\mathrm{i}+\theta \mathrm{ECM}_{\mathrm{t}-\mathrm{i}}+\Sigma_{\mathrm{t}} \ldots 3.3$

The lagged residual term (ECM) above shows the disequilibrium in long run relationship ( $\mu_{\mathrm{t}}$ in equation 3.1 ).

In estimating equation (3.3) above, the null hypothesis of no cointegration among the variables, defined by;

Ho $: \lambda_{1}=\lambda_{2}=\lambda_{3}=\lambda_{4}=\lambda_{5}=\lambda_{6}=\lambda_{7}=0$

is tested against the alternative:

$\mathrm{H}_{1}: \lambda_{1}=\lambda_{2}=\lambda_{3}=\lambda_{4}=\lambda_{5}=\lambda_{6}=\lambda_{7} \neq 0$

F-test was conducted to test for cointegretion. This test has two sets of critical values; one set assumes that all variables are of order $\mathrm{I}(0)$ and the other set assumes that they are I(1). If the computed F - statistic falls above the upper bounds critical value, which corresponds to I(1) variables, the null hypothesis of no cointegration is rejected. If the computed F - statistic falls below the lower bound, which corresponds to $\mathrm{I}(0)$, the null hypothesis of no cointegration is not rejected. If the computed $\mathrm{F}$ - statistic falls between the two bounds, the result is inconclusive. The orders of the lags are selected by the Akaike information Criteria

The coefficient of $\mathrm{ECM}_{\mathrm{t}-1}$ is expected to be negative and fractional. It measures the speed of adjustment to equilibrium after a shock.

\subsection{Post Estimation Tests}

Robustness residual tests such as Ramsey Reset test (for Model specification), Jarque-Bera normality test, Breusch-Pagan-Godfrey heteroscedasticity test and Lagrange multiplier (LM) test for serial correlation were conducted.

Econometric software used in the estimation is E-view, version 9.

\section{Presentation And Analysis Of Results}

\subsection{Descriptive Statistics}

Table 2. Result of the Descriptive Statistics

\begin{tabular}{|l|l|l|l|l|l|l|l|}
\hline Variable & Mean & Media & $\begin{array}{l}\text { Maximu } \\
\mathbf{m}\end{array}$ & $\begin{array}{l}\text { Minimu } \\
\mathbf{m}\end{array}$ & Std.Dev & Skewness & Kurtosis \\
\hline RGDPR & 5.727273 & 5.850000 & 14.60000 & - & 3.665045 & 0.191072 & 3.213481 \\
& & & & 1.600000 & & & \\
\hline CORRUPT & 2.050000 & 2.200000 & 2.800000 & 0.700000 & 0.618562 & -0.585065 & 2.249177 \\
\hline DEMO & 0.863636 & 1.000000 & 1.00000 & 0.000000 & 0351250 & -2.119252 & 5.491228 \\
\hline LEXB & 49.07273 & 49.10000 & 53.80000 & 42.50000 & 3.055546 & -0.163794 & 2.141589 \\
\hline POPGR & 3.090909 & 3.100000 & 4.900000 & 2.800000 & 0.438514 & 3.312062 & 14.52945 \\
\hline LGEXP & 7.605335 & 7.686811 & 9.024263 & 5.820735 & 0.944796 & -0.367722 & 1.928204 \\
\hline
\end{tabular}

Source: Author's computation from E-view, version 9 
The result of the descriptive statistics presented in table 2 above shows that life expectance at birth (LEXB) has the highest mean of 49.07. This is followed by government expenditure (LGEXP) with the mean of 7.61; real GDP growth rate (RGDP) with the mean of 5.73 and population growth rate (POPGR), which has the mean of 3.09. Democracy (DEMO) has the least mean of 0.86 followed by corruption with the mean of 2.05. RGDPr has the highest standard deviation; the higher the standard deviation, the higher the variability of the series. Democracy and corruption have the least variability with the standard deviations of 0.35 and 0.62 respectively. RGDPr, POPGB and LEXB are positively skewed while corruption and democracy are negatively skewed, which implies that they are falling more than the other variables. The values of the kurtosis are different from 3, which is an indication of non-normal distribution for some of the series.

\subsection{Unit Root Tests}

Unit root tests, applying Augmented Dickey - Fuller (ADF) and Philips-Perron (PP), were conducted. This is to ensure that none of the variables is I (2), which is the condition for the application of ARDL procedure.

Table 3. Results of Augmented Dickey-Fuller (ADF) and Philips- Perron (PP) Unit Root Test

\begin{tabular}{|l|l|l|l|l|l|}
\hline & \multicolumn{2}{|l|}{$\begin{array}{l}\text { ADF Statistic (with } \\
\text { trend \& Intercept) }\end{array}$} & \multicolumn{2}{l|}{$\begin{array}{l}\text { PP Statistic (with } \\
\text { trend \& intercept) }\end{array}$} & $\begin{array}{l}\text { Order of } \\
\text { Integration }\end{array}$ \\
\hline Variables & Level & $\begin{array}{l}\text { First } \\
\text { difference }\end{array}$ & Level & $\begin{array}{l}\text { First } \\
\text { difference }\end{array}$ & \\
\hline RGDPr & -1.89296 & -5.418327 & -2.813090 & -9.9208383 & $\mathrm{I}(1)$ \\
\hline CORRUPT & -3.229651 & -5.76375 & -3.427872 & -5.055897 & $\mathrm{I}(1)$ \\
\hline POGR & -4.160877 & -7.018123 & -4.160877 & -18.46702 & $\mathrm{I}(0)$ \\
\hline LEXB & -6.343930 & -30.20406 & -3.724279 & -9.131202 & $\mathrm{I}(0)$ \\
\hline LGEXP & -2.897553 & -7.435472 & -2.813090 & -9.920838 & $\mathrm{I}(1)$ \\
\hline
\end{tabular}

MacKinnon critical values are: - $4.498307(1 \%),-3.658446(5 \%)$ and $-3.268973(10 \%)$ for RGDPr, CORRUPT \& LGEXP - $4.467895(1 \%),-3.644963(5 \%)$ and $3.261452(10 \%)$ for POPGR \& LEXB

Source: Author's computation from E-view, version 9.

The results of the unit root tests from both ADF and PP show that population growth rate (POPGR), which represents the growth of labour, and the life expectancy at birth (LEXB), which represents the health outcome, are stationary at levels. This means that they are $\mathrm{I}(0)$ variables, which implies that they do not contain unit root. On the other hand, the growth rate of real GDP, corruption and government expenditure are stationary at first difference, that is, they are I(1) variables. Therefore, they contain unit root. The existence of unit root in some of the variables necessitates the test for cointegration. This is in order to find out whether a linear combination of non-stationary variables could yield stationary in the long run. 


\subsection{Cointegration Test}

The results of the unit root tests above show that the series contain a mixture of $\mathrm{I}(0)$ and $\mathrm{I}(1)$ variables. Thus, ARDL approach is considered the most appropriate for testing for cointegration between the dependent and independent variables. The result of ARDL, applying the bounds test, is presented in Table 4. below:

Table 4. Result of ARDL Bounds Test

ARDL Bounds Test

Date: 07/01/19 Time: 12:03

Sample: 19962017

Included observations: 21

Null Hypothesis: No long-run relationships exist

\begin{tabular}{lll}
\hline \hline Test Statistic & Value & K \\
\hline \hline F-statistic & 6.302938 & 5 \\
\hline \hline
\end{tabular}

Critical Value Bounds

\begin{tabular}{lll}
\hline \hline Significance & I0 Bound & I1 Bound \\
\hline \hline $10 \%$ & 2.26 & 3.35 \\
$5 \%$ & 2.62 & 3.79 \\
$1 \%$ & 3.41 & 4.68 \\
\hline \hline
\end{tabular}

Source: Author's Computation from E-view, version 9

The result of the bounds test shows that the value of F-statistic is 6.302938, which is higher than the upper bounds [1(1)] critical values at 5 percent and I percent respectively. This implies that there is cointegration between economic growth (the dependent variable) and independent variables, which are corruption, democracy, life expectancy at birth, population growth rate and government expenditure. Therefore, there is long run relationship between economic growth and independent variables.

Since cointegration between the variables has been established, the next step is to test for the short run and long run impact of corruption, democracy and other control variables (life expectancy at birth, population growth rate and government expenditure) on economic growth in Nigeria. 


\subsection{Presentation and Discussion of Results/Congruence with Empirical Studies}

Table 5. ARDL Short run and long run results

(a) ARDL Short Run Result

ARDL Cointegrating And Long Run Form

Dependent Variable: RGDPR

Selected Model: ARDL(1, 0, 0, 1, 0, 0, 1)

Date: 07/02/19 Time: 20:10

Sample: 19962017

Included observations: 21

Cointegrating Form

\begin{tabular}{lllll}
\hline \hline Variable & Coefficient & Std. Error & t-Statistic & Prob. \\
\hline \hline D(CORRUPT) & -6.706663 & 23.441377 & -0.286104 & 0.7801 \\
D(DEMO) & -15.519750 & 43.428974 & -0.357359 & 0.7276 \\
D(LEXB) & -0.039441 & 0.458357 & -0.086049 & 0.9330 \\
D(POPDR) & -0.116649 & 0.975291 & -0.119604 & 0.9070 \\
D(LGEXP) & 5.077642 & 2.448644 & 2.073654 & 0.0624 \\
D(CORRUPT * DEMO) & 5.353352 & 23.358550 & 0.229182 & 0.8229 \\
CointEq(-1) & -0.683618 & 0.115333 & -5.927313 & 0.0001 \\
\hline \hline
\end{tabular}

Cointeq $=$ RGDPR $-(-9.8105 *$ CORRUPT $22.7024 *$ DEMO3.7332*LEXB

$-0.1706 *$ POPDR + 7.4276*LGEXP + 13.7803*CORRUPT*DEMO+ 146.8624 )

(b) ARDL Long Run Result

Long Run Coefficients

\begin{tabular}{lllll}
\hline \hline Variable & Coefficient & Std. Error & t-Statistic & Prob. \\
\hline \hline CORRUPT & -9.810549 & 34.202233 & -0.286839 & 0.7796 \\
DEMO & -22.702388 & 63.338449 & -0.358430 & 0.7268 \\
LEXB & -3.733235 & 0.874375 & -4.269603 & 0.0013 \\
POPDR & -0.170635 & 1.427838 & -0.119506 & 0.9070 \\
LGEXP & 7.427606 & 3.616708 & 2.053692 & 0.0646 \\
CORRUPT*DEMO & 13.780327 & 34.076757 & 0.404391 & 0.6937 \\
C & 146.862405 & 71.338795 & 2.058661 & 0.0640 \\
\hline \hline
\end{tabular}

Source: Author's Computation from E-view, version 9.

The results of the short run and long rum of ARDL above show that corruption has negative impact on economic growth in Nigeria during the period covered by the study. This negative impact of corruption on economic growth agrees with the findings of the empirical studies by Mauro (1995), Mo (2001), Isse and Abdiweli (2003), Omenka (2013), and Aliyu (2017). 
Therefore, the result of this study supports the hypothesis that corruption sands the wheels of bureaucracy in Nigeria.

The coefficient of dummy variable interaction with corruption (CORRUPT* DEMO) is positive in both the short run and long run. Since the coefficient of corruption is negative and the coefficient of dummy variable interaction term is positive, democratic stability in Nigeria helps in mitigating the negative impact of corruption on economic growth in the country. This finding agrees with the result of the empirical study by Shabbir (2017), who finds that democracy plays an essential role in determining the corruptiongrowth relationship.

In the case of democracy, its impact on economic growth is negative both in the short run and long run. The negative sign of democracy deviates from the a priori expectation. This result is not surprising in Nigeria because the electoral process does not allow the citizens to expel the politicians who engage in corrupt practices. The negative sign of the coefficient of democracy agrees with the empirical findings by Aminu, Gbenga and Bolaji (2014), whose result shows that changes in democracy reduces output in the economy in Nigeria.

Life expectancy has negative impact on economic growth in both short run and long run. In the long run, its impact on growth is negative and significant, with the probability value of 0.0013 , which is less than 0.05 significant level. The negative sign of the coefficient of life expectancy deviates from a priori expectation because life expectancy facilitates economic growth.

Population growth rate has negative impact on economic growth in Nigeria in both the short run and long run. This is a deviation in the expectation. The implication of this finding is that the higher the rate of population growth, the more the number entering into labour market. Thus, for a given level of investment, each worker tends to have less capital stock which leads to low productivity level and hence, retards economic growth.

Government expenditure has positive and fairly significant impact on economic growth in Nigeria. The probability values are 0.0624 and 0.0646 in the short run and long run respectively, which are significant only at 10 percent levels. The positive signs are in line with the a priori expectation because there is emphasis on private sector development in Nigeria. This lowers taxation and encourages private investment which promotes growth.

The error correction term in correctly signed; it is negative and fractional. Its value is -0.683618 , with the probability value of 0.0001 , shows that it is significant. It shows that 68.4 percent of previous year shock is returned to equilibrium in current year. This implies that approximately 68.4 percent of any disequilibrium in economic growth (RGDPr) is corrected by 
the independent variables annually. This shows a high speed of adjustment to equilibrium after a shock.

\subsection{Robustness Tests}

The diagnostic tests conducted for robustness of the model include Jarque-Bera test for normality, Breusch-Godfrey serial correlation LM test, Breusch-Pagan-Godfrey test for heteroscedasticity and Ramsey Reset test for model specification.

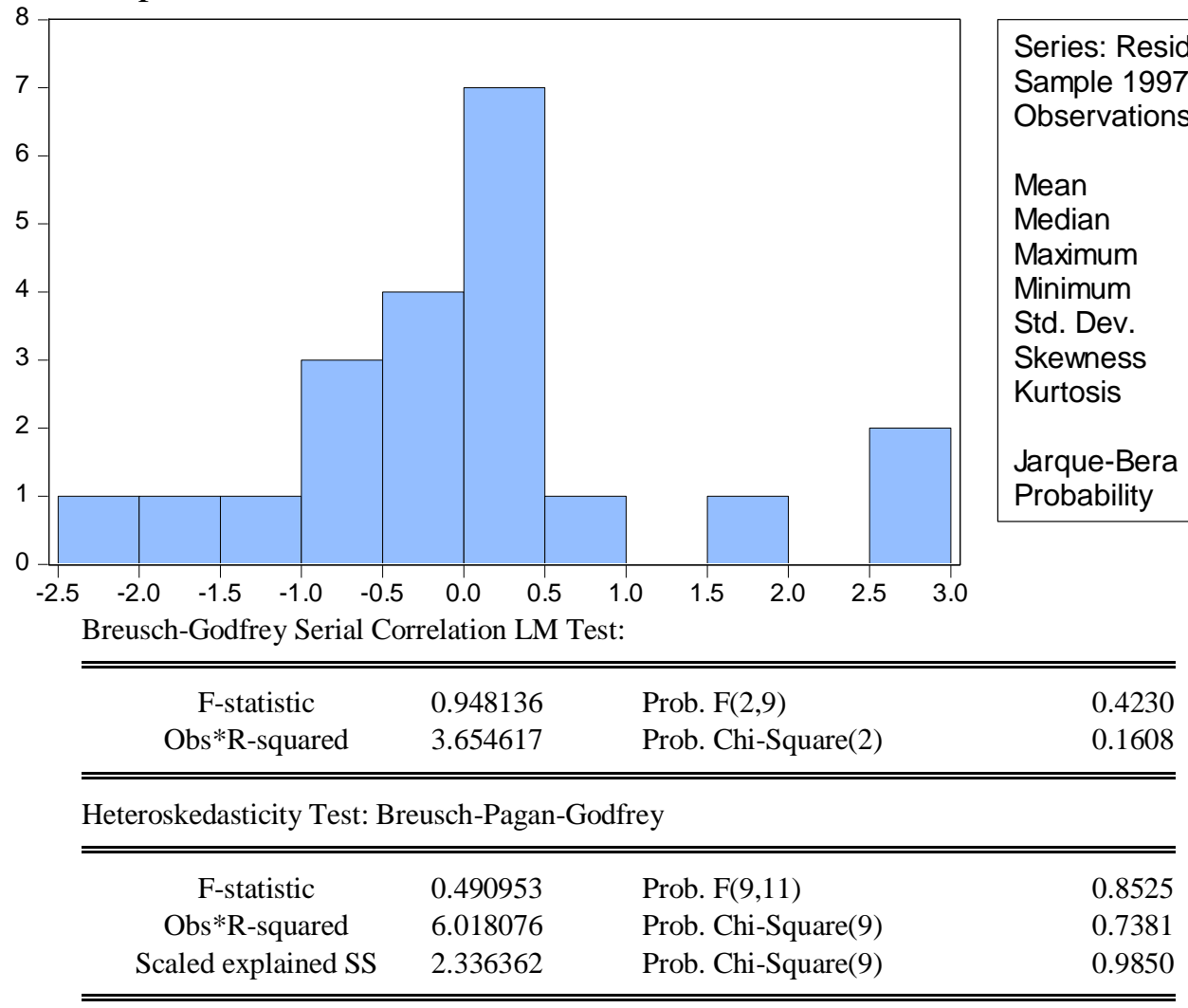

Ramsey RESET Test

Equation: UNTITLED

Specification: RGDPR RGDPR(-1) CORRUPT DEMO LEXB LEXB(-1)

POPDR LGEXP CORRUPT*DEMO CORRUPT(-1)*DEMO(-1) C

Omitted Variables: Squares of fitted values

\begin{tabular}{cccc}
\hline \hline & Value & df & Probability \\
\cline { 2 - 4 } t-statistic & 1.775054 & 10 & 0.1063 \\
F-statistic & 3.150817 & $(1,10)$ & 0.1063
\end{tabular}

Source: Author's Computation from E-view version 9.

The probability values of the various diagnostic tests above are greater than 0.05 respectively. This implies that the residuals are normally distributed, there is no serial correlation problem and that the residuals are 
homosecedastic. It also implies that the functional form of the model is well specified. The foregoing shows that the results of the parameter estimates are valid and can be used for forecast and policy formulations.

\section{Summary, Conclusion and Recommendations} 5.1 Summary of Findings and Conclusion.

The study examines the impact of corruption on economic growth in Nigeria's stable democracy for the period 1996 - 2017. Annual time series data on corruption perception index, which were collected from Transparency International, were used to measure corruption. Data for the dependent variable (real GDP growth rate) and other control variables (life expectancy at birth, population growth rate and government expenditure) were collected from CBN Statistical Bulletin, 2017 edition and Annual Report (various issues). A dummy variable for democracy was also used to assess whether democracy helps in mitigating the negative effect of corruption on economic growth in Nigeria.

The empirical results show that there is long run relationship between economic growth and independent variables (corruption, democracy, life expectancy at birth, population growth rate and government expenditure) in Nigeria during the period covered by the study. It is also found that corruption has negative impact on economic growth in Nigeria during the period covered by this study. The result also shows that democratic stability in Nigeria helps in mitigating the negative impact of corruption on economic growth in Nigeria.

The results also show that life expectancy significantly retards economic growth in the long run; population growth rate retards economic growth in Nigeria; and that government expenditure improves economic growth in Nigeria.

The conclusion drawn is that corruption retards economic growth in Nigeria, which is in line with the hypothesis that corruption sands the wheels of bureaucracy. Secondly, stable democracy in Nigeria helps in mitigating the negative effect of corruption on economic growth in Nigeria.

\subsection{Recommendations}

Based on the findings, the following recommendations are made:

Corruption and democracy have negative impact on economic growth. This implies that the negative impact of corruption is worsened by the political process in which corruption occurs. Therefore, government efforts at curbing corruption should be intensified. The various anti-corruption agencies like the EFCC and ICPC should, without fear or favour, bring to book all corrupt politicians and bureaucrats in our public service. 
The empirical result shows that democratic stability mitigates the negative impact of corruption on economic growth in Nigeria. The government should therefore enforce the democratic principles such as the rule of law, government responsiveness to public opinion; freedom of speech, freedom of religion and association, and most importantly, political participation by the citizens in the country. Such democratic principles, when enforced, will provide more stable environment for investments and hence, promote growth.

Life expectancy at birth, which represents health outcome, has negative and significant impact on economic growth. The significant impact implies that such funds were allocated to the health sector while the negative impact implies diversion of such funds. The government, besides increasing budgeting allocation to health sector, should also monitor the end use of such funds in order to avoid diversion. This is because health sector spending is one of the indirect beneficial effects of democracy on growth.

\section{References:}

1. Aliyu, S.U.R (2017). Revenue Reforms, Corruption and Economic Growth: The Nigerian Experience (1999 - 2016). Paper Presented at the FAAC Technical Workshop held in Mina, Niger State, Nigeria on the $6^{\text {th }}-7^{\text {th }}$ November, 2017.

2. Aminu, U. (2014). Democracy and the Performance of the Nigerian Economy, International Journal of Humanities and Social Sciences. 4, 10(1), (August 2014),191-207.

3. Amira, Z. (2014). Corruption's and Democracy's effects on Economic Growth. MPRA on line at https://mpra.ub.unimnenchen.de/54535/MPRA paper no. 54535, posted 19 March, 2014 15:03 UTC.

4. Central bank of Nigeria (2017). Annual Report, 2017.

5. Central Bank of Nigeria (2017). Statistical Bulletin, 2017.

6. Clague, C., Keefer, P., Knack, S. \& Olson, M. (1996). Property and Contract Rights in Autocracies and Democracies. Journal of Economic Growth, 1, 243-276.

7. Dickey, D.A.\&Fuller,W.A.(1979).Distribution of the Estimators for Autoregressive Time series with a unit root. Journal of the American Statistical Association,74,427-431.

8. El-Rufai, N. (2003). Is Liberal Democracy encouraging Corruption and corrupt practices? The privatization process in Nigeria. Social Science Academy of Nigeria,6(2),1-15.

9. Hodge, A., Sriram Shankar, D.S., Prasada,R. \& Alan, D. (2011). Exploring the links between corruption and Growth. Rewiew of Development Economics, 15,474-90. 
10. Huntington, S.P.(1968). Political order in changing socities.New Haven: Yale University Press.

11. Federal Republic of Nigeria (1987). Report of the Political Bureau, Abuja: Federal Government Press.

12. Isse, S.H \& Abdiweli, M.A (2003). Determinants of Economic Corruption: A Cross Country Comparison, Cato Journal, 22 (3).

13. Knack, S. \& Keefer, P. (1995). Institution and Economic Performance: Cross Country tests using alternative institutional measures. Economics and Politics, 7, 207 - 227.

14. Leff, N.H. (1964). Economic Development through Bureaucratic corruption. The American Behavioral Scientist, 8, 8-14.

15. Leys, C. (1970). What is the problem about corruption? In A.J. HeidenHeimer (ed), Political Corruption: Readings in Comparative Analysis. New York: Holf Rinehart.

16. Lui, F.T. (1985). An Equilibrium Queuing Model of Bribery. Journal of Political Economy, 93, 760 - 781

17. Mauro, P. (1995). Corruption and Growth. The Quarterly Journal of Economics, 110 (3), 681-712.

18. Mauro, P. (1998). Corruption and composition of government expenditure. Journal of Publi Economics, Doi: 10.1016/S0047-2727 (98) 00025-5

19. Meon, P.G. \& Sekkat, K. (2005). Does corruption Grease or sand the wheels of Growth? Public Choice, 122, 69-97 doi; 10. 1007/ 511127005-3988-0.

20. MO, P.H (2001). Corruption and Economic Growth. Journal of Comparative Economics, 29 (1), 66-79

21. Myrdal, G. (1968). Asian Drama: An Inquiry into the poverty of Nations. New York: Pantheon.

22. National Planning Commission (2004). National Economic Empowerment and Development Strategies (NEEDS). Abuja: National Planning Commission.

23. Nye, J. S. (1967). Corruption and political Development: A CostBenefit Analysis. The American Political Science Review, 61, 417-27.

24. Obasanjo, O. (2000). An address on the occasion of the formal signing of the Bill of law to prohibit and punish bribery and corruption of public officers and other persons in Nigeria, Abuja (2000).

25. Odubunmi, A.S \& Agbelade, L.I. (2014). Corruption and Economic Growth in Nigeria. Journal of Economics and Sustainable Development, 5(6), 45-56.

26. Oguonu, C.N. \& Ezeibe, C.C. (2014). Political Corruption and Economic Growth in Nigeria. Mediterranean Journal of Social Sciences, 5(27), 69-76. 
27. Omenka. I.J. (2013). The Effect of Corruption on Development in Nigeria. IOSR Journal of Humanities and Social Science (IOSE JHSS), 15(6), 39-44.

28. Pesaran, M.H., Shin, Y. \& Smith, R.J. (2001). Bounds testing approaches to the analysis of level relationships. Journal of Applied Econometrics, 16,289-326.

29. Philips, P.C.B .\& Perron, P. (1988). Testing for a unit root in time series regression. Biometrica, 75,335-346.

30. Rose-Ackerman, S. (1999). Corruption and Government: Causes, Consequences and Reform. Cambridge, UK: Cambridge University Press.

31. Shabbir, G. (2007). Corruption, Democracy and Economic Growth: Does conditionality matter? Pakistan Economic and Social Review, 55 (1), 99-117.

32. Shleifer, A. \& Vishny, R.W. (1993). Courrption and Growth.

33. The Quarterly Journal of Economic. 108, 599-617.

34. Tanzi, V. \& Davoodi, H. (1997). Corruption Public Investment and Growth. IMF Working paper (WP/97/139).

35. Transparence International (2017). Corruption Perception Index.

36. Wedeman, A. (1997). Looters, Rent Scrapers, and Dividendcollectors: Corruption and Growth in Zaire, South Korea and Philippines. Journal of Developing Areas, 31, 457 - 478.

37. World Bank (1997). Helping Countries Combat Corruption: The Role of the World Bank. New York: Oxford University Press. 